\title{
ASSESSMENT OF THE CORRELATION BETWEEN THE PUS CELL COUNT AND THE PH LEVEL OF VIABLE ISOLATES OF URINE SAMPLES FROM URINARY TRACT INFECTIONS AMONG PRIMARY SCHOOL BOYS IN ADO LOCAL GOVERNMENT, EKITI STATE, NIGERIA
}

\author{
Oluwafoise, B. G. \\ Department of Biology, \\ College of Education, \\ Ikere-Ekiti, Ekiti State, \\ Nigeria.
}

\begin{abstract}
A total number of 240 urine samples from primary school boys were collected from different primary schools within AdoEkiti. The urine samples were collected for isolation, cultural characteristics and biochemical identification of enteric bacteria and other UTI pathogens which may be present in the urine sample of children attending public schools in AdoEkiti. Insignificant growth occurred in 200 (83.33\%) of the isolate, 33 (13. 75\%) of the samples did not have any growth, while 7 (2.92\%) sample had significant growth. Pus cell count was carried out to determine the correlation between the pus cell count the PH of the seven samples with significant growth. The result showed that there was a direct correlation between the pus cell count and the $\mathrm{pH}$ of samples with significant growth, showing that $50 \%$ of children with significant bacteriuria had significant pus cell count, with alkaline $\mathrm{pH}$ in their urine.
\end{abstract}

\section{INTRODUCTION}

Urinary tract infection (UTI) is an infection that occurs when bacteria gain access into urinary system i.e the bladder and the kidney. UTI is one of the most common bacterial infections in children and requires prompt recognition, treatment and investigations (Fenwick, Briggs, and Hawke, 2010).

Urinary tract infection represents one of the most common types of infectious disease encountered in the practice of medicine today. The infection may cause significant morbidity, inconveniency and anxiety in children and their families and result in considerable consumption of resources (Jantunen et al, 2010). Generally, any situation that leads to state of urine in the bladder frequently increases the chance of UTI as this enhances the multiplication of bacteria (Fenwick et al, 2010).

Urinary trait infection can be categorized into two areas of involvement. This includes (i) cystitis (bladder infection) and (ii) pyelonephritis (kidney infection) cystitis implies a superficial mucosal inflammation of the bladder, clinically characterized by dysuriq, urinary urgency, nocturia, supra public discomfort, and less often, hematuria and urinary inconveniency. (Ardissino et al, 2003).

Symptoms of urinary tract infections are usually non-specific in a baby or child. Unexplained fever or fever without an obvious source is the only consistent symptoms among young children with UTI. 
Urinary tract is diagnose by testing the urine for the present of pus cells and bacteria (Jodal, 2017).

Antibiotic to kill the bacteria are use in the treatment of UTI. Children are often admitted to hospital for more aggressive and effective antibiotics treatment by injecting the antibiotics directly in to the blood stream through a drip or what is termed intravenous antibiotics treatment (Vaillancourt et al, 2017).

Pus is the result of the body's natural immune system automatically responding to an infection usually by bacteria of fungi. The normal range of pus cell in normal healthy male urine is o -1 pus cell per hpf or high power filed under the microscope (chaudhari, et al, 2016). The presence of pus cells urine is often indication of an urinary tract infection. However UTI may affect different parts of the urinary trait causing different condition. If it infect the urethra, the infection is called urethritis. After this the infection might go further to infect the bladder, with is a condition known as cystitis. If the urine blocks the urinary tract, it may go further to infect the kidneys and cause the disease called pylonephritics. If pus cell are collected along the course of the urinary tract, it causes a condition known as abscess (Chang and shortliffe, 2006). If pus cell are present in the urine, the urine become dark and cloudy. It may even have a shade of red colours because of blood presence in the urine. It is also common that the urine has a bad smell (Vaillancourt, et al, 2017).

Ordinarily when urine starts to look cloudy instead of being purely clear, the condition one may be suffering from is known as pyuria which means that there are too many pus cells in the urine. The presence of pus cells in the urine is often an indication of a urinary trait infection, commonly known as UTI, and therefore apart from pyuria, children may suffer from other unpleasant symptoms. UTI can cause painful or burning sensation while passing urine, accompanied by more frequent urination or feel a strong urge to urinate but resulted in passage of only few drops of urine (stein et al, 2015).

The normal range of pus cell is $0-5,8-10$ range of pus cell indicates the presence of bacteria, hence the presence of urinary trait infection.
The Urine $\mathrm{pH}$ level is the level of the acidity or alkalinity (basic) of the urine. However, the urine $\mathrm{pH}$ test measures the acidity of urine. (Israni and Kasiske, 2011). Healthy urine has a $\mathrm{pH}$ from 3.5 to 6.5 , i.e on the acid range of $\mathrm{pH}$. A $\mathrm{pH}$ of 4 is strongly acidic, 7 is neutral (neither acidic or alkaline) and 9 is strongly alkaline (Israni and Kasiske, 2011).

\section{MATERIALS AND METHOD}

A mid-stream catch of voided first early morning urine was collected from primary school children whose age ranges between 5-12 years. Urine samples collective were taken to the laboratory for processing within 12 hours of collection 5 to $6 \mathrm{ml}$ of urine sample were placed in $12 \mathrm{ml}$ test tubes and centrifuged at 2000 revolution per minutes (r. p. m) for 5minuts. The supernatants were discarded and the tubes were tapered vigorous. By to resuspend urine sediments. An aliquot of the sediment were placed on a glass slide and covered with a cover slip and then examined microscopically for the presence of epithelial cells, leucocytes bacterial cells, sulpha crystals, red blood cells, white blood cells, and pus cells. The $\mathrm{pH}$ of different urine samples were determinant using a litmus paper test.

\section{RESULTS}

A total of 240 urine sample from primary school boys were collected from different primary schools within Ado Ekiti. These urine samples were collected for isolation, cultural characteristics and biochemical identification of enteric bacteria and UTI pathogen which may be present in the urine specimens of children attending public school in Ado Ekiti.

Insignificant growth occurred in 200 $(83.33 \%)$ of the isolate, 33 of the sample did not have any growth $(13.75 \%)$ while $7(2.92 \%)$ of the urine samples had significant growth (table 1).

Pus cell count was carried out to determine if the 7 sample with the significant growth have symptomatic or asymptomatic types of infection. The result showed that there was correlation between significant pus cell count, symptomatic bacteriuric and the $\mathrm{pH}$ of the corresponding urine samples, as shown in table 1 .

Table 1: Pus cell count and pH of urine sample of bacteriuric primary school boys

\begin{tabular}{cccc}
\hline Isolates & Bacteriuria & Pus cell count & PH \\
\hline 10 & Asymptomcitic & Nil & 5 \\
18 & Symptomatic & Significant & 8 \\
100 & Symptomatic & Significant & 7 \\
120 & Asymptomatic & Nil & 6 \\
200 & Asymptomatic & Significant & 5.5 \\
203 & Symptomatic & Significant & 8 \\
210 & Symptomatic & & 8 \\
\hline
\end{tabular}




\section{DISCUSSION AND CONCLUSION}

Urinary trait infection is a problem of great medical importance worldwide. Urinary trait infections have been known to be caused majorly by the family of gram- negative rod- shaped aerobic organism called Enterobacteriaceae.

In this work, urine samples were collected from 240 apparently healthy primary school boys within Ado-Ekiti. 200 (83.33\%) urine samples showed an significant growth, 33 (13.75\%) of the samples did not give any growth while 7 (2. 92\%) showed a significant bacteria count.

In this work, the result shown that there was correlation between pus cell count, symptomatic bacterieria and $\mathrm{pH}$ of the corresponding isolates. This can be seen in table 1. A significant pus cell count was obtained in 4 out of the 7 isolated samples, with a corresponding $\mathrm{pH}$ range between 7-8 recorded. The remaining 4 isolates showed an insignificant pus cell count and asymptomatic baceterueria resulting in a $\mathrm{pH}$ range between 5-6.

\section{REFERENCES}

1. Abitbol, C., Zilleruelo, G., Freudlich, M., Strauss, J. (2015). Quantitative of proteinuria with urinary proten/creatinine ratios and random testing with dipsticks in nephorotic children. J. Pediatr 116:43-47.

2. Ardissino, G., Dacco, V., Testa, S. (2003). Epidemiology of chronic renal failure in children: date from the Italkid project. pediatrics. 2003:111(4ptl):e382-7

3. Chang, S.L., Shortliffe, L.D. (2006). Pediatric urinary trait infections. Pediatr Clin North AM 53:379.

4. Chaudhari, P., Monuteaux, M., Bachur R. (2016). The optimal diagnoshc threshold of pyria for identifying UTI in young infants. Pediatrics 138(5): e 20162370

5. Fenwick, E.A., Briggs, A.H., Hawke, C.L., (2010). Management of urinary trait infection in general practice: a cost effectiveness analysis. $\underline{\text { BrJGenPrait }}$ 50(457):635-9.

6. Hoberman, A., Wald, E.R., Penchansky, L., Reynolds, E.A. Youngs. (2015). Enhanced urinalysis as a screening test for urinary trait infection. Pediatrics 91(6) 1196 1199 pmid:8123075.

7. Israni, A.K., Kasiske, B.L. (2011). Laboratory assessment of kidney disease: aeglomerular filtrate rate, urinalysis, and proteinuria in children.

8. Jantunen, M.E, Siitonen, A., Ala-Houhala,M., Ashorn, P. (2010). Predictive factors associated with significant urinary trait abnormalities in infants with pylonephritis. Pediatr.Infect Dis J. 20(6):597-60.

9. Jodal, U. (2017). The natural history of bacteriuria in childhood. Infet Dis Clin North Ain.

10. Jugannath, V.A., Fedorowicz, Z., Sud, V., Varma, A.K., Haje-brahimi, S. (2012). Routine neonatal circumcision for the prevension of urinary tract infection in Infancy.
11. Nuutinen, M., and Uhari, M. (2001). Recurrence and follow-up after urinary tract infection under the age of 1 year. Padiatr Nephrol 16(1) 69-72

12. Schnadower, D., Kuppermann, N., Macias, C.G. (2014). Outpatient management of young febrile infants with urinary tract infections. Pediatr Emerg Care 30:591.

13. Stein, R., Dogan, H.S., Hoebeke, P. (2015). Urinary trait infection in children. EAU/ESPUguidelines. EurUrol 67-546.

14. Strohmeier, Y., Hodson, E.M., Willis, N.S. (2014). Antibiotic for acute pyelonephritis in children.

15. Vaillancourt, S., McGillivray, D., Zhang, X., Kramer, M.S. (2017). To clean or not to clean: effect on contamination rate in midstream urine collections in toilet-traned children. Pediatrics, 119;1288-1293. 